\title{
Iron Metabolism in Patients Undergoing Regular Dialysis Therapy
}

\author{
B. BROZOVICH, W. R. CATTELL, M. F. COTTRALL， M. M. GWYTHER, J. M. MCMILLAN \\ J. S. MALPAS, A. SALSBURY, N. G. TROTT
}

British Medical Fournal, 1971, 1, 695-698

\section{Summary}

Thirteen patients with chronic renal failure maintained on regular renal dialysis were studied. Seven proved to have iron deficiency on the basis of marrow iron studies, reticulocyte iron uptake, and saturation of the serum iron-binding capacity. They absorbed iron when given it by mouth and were able to utilize it for haemoglobin formation. Iron-deficient patients given $600 \mathrm{mg}$ of ferrous sulphate daily for three months showed an increase in haemoglobin, but the failure to replace stores of iron is probably related to their relatively limited ability to absorb iron and the variable but sometimes considerable blood loss occurring with each dialysis.

The loss may be occult, and prolonged iron therapy may be required. This is most safely achieved by giving iron by mouth.

\section{Introduction}

The anaemia of chronic renal failure is commonly normocytic and normochromic. Iron-deficiency anaemia may occur and when transfusion is avoided is not uncommon in patients undergoing regular dialysis therapy. Controversy exists regarding the effectiveness of oral iron therapy in such patients

\section{St. Bartholomew's Hospital, London E.C.1}

B. BROZOVICH, M.D., PH.D., Lecturer, Department of Haematology W. R. CATTELL, M.D., F.R.C.P.ED., Consultant Physician J. S. MALPAS, D.PHIL., M.R.C.P., Senior Lecturer in Medicine

Institute of Cancer Research, Royal Marsden Hospital, Sutton, Surrey M. F. COTTRALL, B.A., M.Sc., Member of Scientific Staff, Physics

M. M. GWYTHER, B.Sc., Member of Scientific Staff, Radiotherapy Research Unit

N. G. TROTT, PH.D., F.INST.P., Reader in Physics Applied to Medicine

Regional Renal Dialysis Unit, St. Leonard's Hospital, London N.1

J. M. MCMILLAN, M.B., M.R.C.P., Senior Registrar

Brompton Hospital, London S.W.3

A. SALSBURY, M.D., Consultant Haematologist resulting in the advocacy of prolonged parenteral iron therapy (Crockett et al., 1967). Such treatment can, however, result in iron overload (Curtis et al., 1969).

The present study was undertaken to re-examine both the absorption of oral iron and the utilization of oral and intravenous iron in patients undergoing membrane dialysis who were carefully studied with respect to intercurrent iron loss.

\section{Methods and Patients}

Thirteen patients on regular dialysis therapy for 3 to 34 months were studied. All were dialysed for a minimum of 28 hours weekly with a Kiil dialyser. They were in good health and received no haematinics at the time of the isotope studies. Two patients (Cases 6 and 13) had had $750 \mathrm{mg}$ and $1,000 \mathrm{mg}$ of iron intravenously 18 and 15 months before the investigation. Case 13 had had 12 pints (6.8 litres) of blood, Case 45 pints (2.8 litres), Cases $1,2,6$ and 11 each 2 pints ( 1.1 litres) previously. The details of diagnosis are given in Table I.

The haemoglobin and packed cell volume (P.C.V.) were measured at the beginning of the study, after each dialysis, and before and after iron therapy by methods described by Dacie and Lewis (1968); serum iron was measured by an automated micromethod (Garry and Owen, 1967) and ironbinding capacity by a semiautomated micromethod (Brozovich and Copestake, 1969). Serum and whole blood folate levels were measured by an automated method described by Millbank et al. (1970). Reticulocyte uptake of iron in vitro has been shown to be a sensitive guide to iron deficiency and was carried out by the method of Brozovich (1971). The use of automated micromethods for all of these determinations reduced the amount of blood taken from these patients to a minimum.

Bone marrow specimens were obtained before the study began and again after iron therapy. They were stained for iron by the method of Rath and Finch (1948). Each was independently examined and graded for its iron content by two of us (J.S.M. and A.S.).

The absorption studies were carried out by means of a whole body counting technique using four $\mathrm{NaI}$ (T1) crystals in a shielded room (Cottrall et al., 1968). Pulse height analysis

TABLE I-Details of Cases

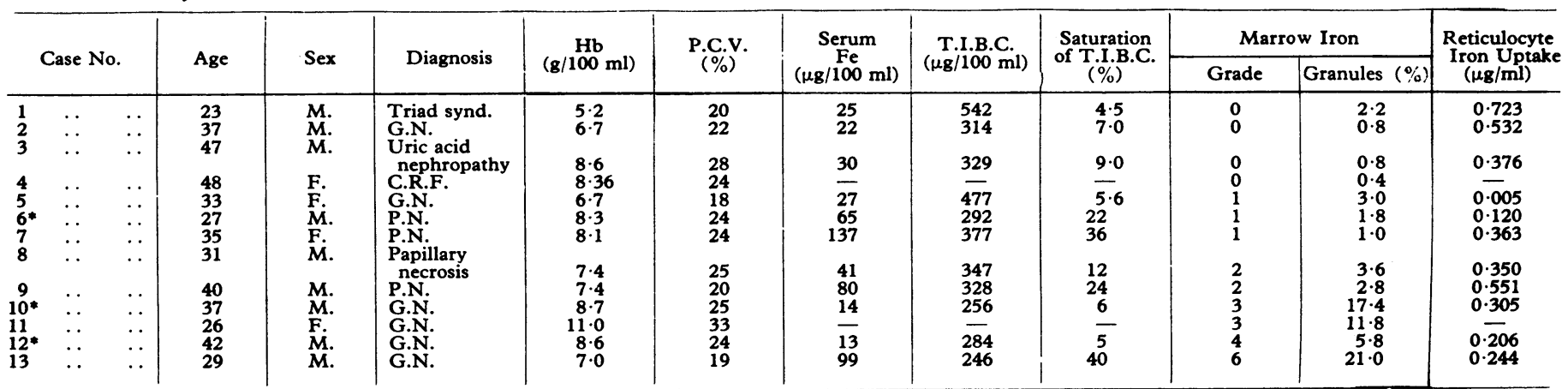

G.N. = Glomerulonephritis. P.N. = Pyelonephritis. C.R.F. = Chronic renal failure-cause unknown. T.I.B.C. $=$ Total iron-binding capacity.

* Treated with analgesics. 
was performed with a multichannel analyser. The fasting subject received a drink containing $1 \mu \mathrm{Ci}$ of ${ }^{59} \mathrm{Fe}$ in the ferrous state; the dose was prepared by adding $1 \mu \mathrm{Ci}$ of ${ }^{59} \mathrm{Fe}$ ferric chloride to a mixture of $50 \mathrm{mg}$ of ascorbic acid and $5 \mathrm{mg}$ of elemental iron as ferrous sulphate. After the dose had been administered the initial count rate for the subject was measured within an hour to obtain the initial $100 \%$ value. Retention of the dose was estimated by repeating the measurement on the fourteenth day. A blood sample was taken at that time and measured under low background conditions in a 3-in $(7.5-\mathrm{cm})$ diameter $\mathrm{NaI}$ (T1) crystal well counter to provide a value for the utilization of absorbed ${ }^{59} \mathrm{Fe}$ for haemoglobin formation.

A second method of measuring absorption was also used (Cottrall and Trott, 1971). A non-absorbable ${ }^{51} \mathrm{Cr}$ chromic chloride marker was given half an hour after the ${ }^{59} \mathrm{Fe}$. Faecal collection was carried out over the next few days, and the percentage of iron and chromium measured. The amount of iron absorbed was then calculated, assuming that both tracers were intimately mixed, and passed through the gut at the same rate. A similar method for measuring iron absorption with ${ }^{131} \mathrm{Ba}$ as the insert marker has been reported (Najean and Ardaillou, 1963; Boender and Verloop, 1969).

The blood clearance half-time of intravenously administered ${ }^{59} \mathrm{Fe}$ was then measured. ${ }^{51} \mathrm{Cr}$-labelled red cells, given at the same time as the ${ }^{59} \mathrm{Fe}$, enabled the red cell mass to be determined simultaneously and reduced the amount of blood taken $-8 \mu \mathrm{Ci}$ of ${ }^{59} \mathrm{Fe}$ and $50 \mu \mathrm{Ci}$ of ${ }^{51} \mathrm{Cr}$ were used. Studies of the loss of iron from these patients were started two weeks later, after the completion of the utilization of the intravenous iron estimation, and were carried out by a method similar to that of Holt et al. $(1967,1968)$. Whole body counting was done at intervals of 14 and then 21 days up to a total of not less than 98 days. In seven of the patients all dialysis lines and membranes, dressings used at the time of attention to the shunts, and blood clots were carefully collected and incinerated; the radioactivity in the ash that had accumulated during the 21-day period was measured, two opposed NaI (T1) crystals in a shielded enclosure being used.

\section{Haematological Studies}

All patients were anaemic with haemoglobin levels ranging from 5.2 to $11 \mathrm{~g} / 100 \mathrm{ml}$ (Table I). P.C.V.s ranged from 18 to $33 \%$. The red cell masses were low, ranging from 507 to 1,230 $\mathrm{ml}$. Good correlation was seen between the red cell mass and the P.C.V. (Fig. 1) but was less satisfactory when compared on a volume per unit weight basis. The mean reticulocyte count was $1.1 \%$ (range 0.7 to $1.8 \%$ ) though examination of most of the marrow smears showed active normoblastic erythropoiesis. Two marrows showed early megaloblastic changes though vitamin $B_{12}$ and serum and red cell folate were normal. Ring sideroblasts were not seen in the marrows in this series. The iron stores were assessed as zero in four patients, grade 1 in three, normal (grade 2 or 3 ) in four, and excessive (grade 4 or 6) in two (Table I). Patients were assessed as iron deficient with marrow iron of grade 0 or 1. Because of fluctuation in haemoglobin levels and P.C.V.s the

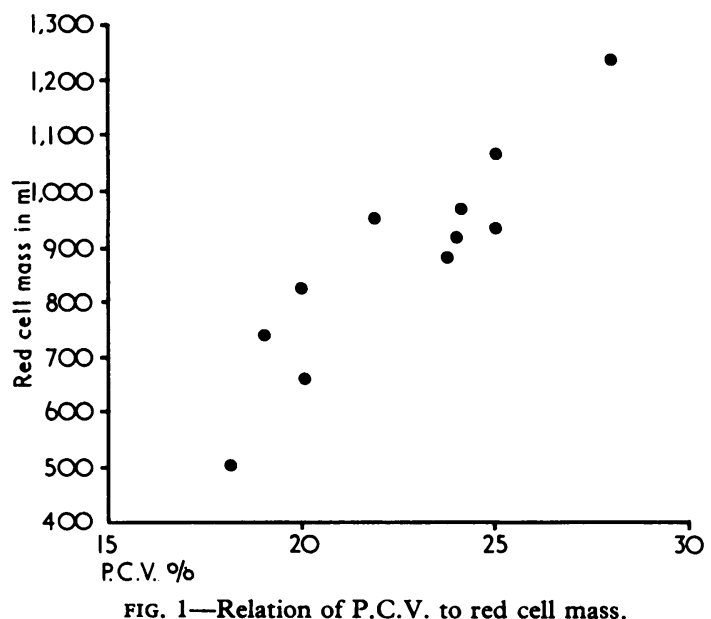

mean of three to five estimations before and after treatment were taken (Table II). Marrow irons were graded before and after three months' treatment with ferrous sulphate $600 \mathrm{mg}$ daily in six patients. Three iron-deficient patients showed a rise in the level of haemoglobin though one failed to show a rise in P.C.V. This change was not observed in the patients with normal marrow iron. None of the iron-deficient patients, however, showed any replenishing of their marrow iron stores.

\section{Biochemical Studies}

The serum iron, iron-binding capacity, and percentage saturation proved to be unsatisfactory guides to the state of the iron stores as indicated by the bone marrow studies. Low levels of saturation were seen in patients with adequate stores (Cases 8 and 10) and in one patient (Case 12) who had increased marrow iron. The reticulocyte uptake of ${ }^{59} \mathrm{Fe}$ showed better correlation with bone marrow grading and marrow iron granule counts. A previous study had shown normal levels of serum vitamin $B_{12}$ in these patients. In 11 patients the serum and red cell folate levels were normal at the time of this study.

\section{Radioisotope Studies}

\section{ABSORPTION AND UTILIZATION}

The results of the radioisotope studies are given in Table III. The retention of iron at $\mathbf{1 4}$ days, the most reliable indication of absorption, is represented in Fig. 2. Retention of iron in these patients has been compared with the retention seen in a control group of iron-deficient anaemic patients studied previously. Iron deficiency had been due to inadequate diet or chronic blood loss in the control group. Retention in this control group was 22 to $95 \%$ of the dose. Measurements of iron retention determined by whole body counting in normal subjects given ferrous salts have shown mean values of about $8 \%$, (Holt et al., 1968).

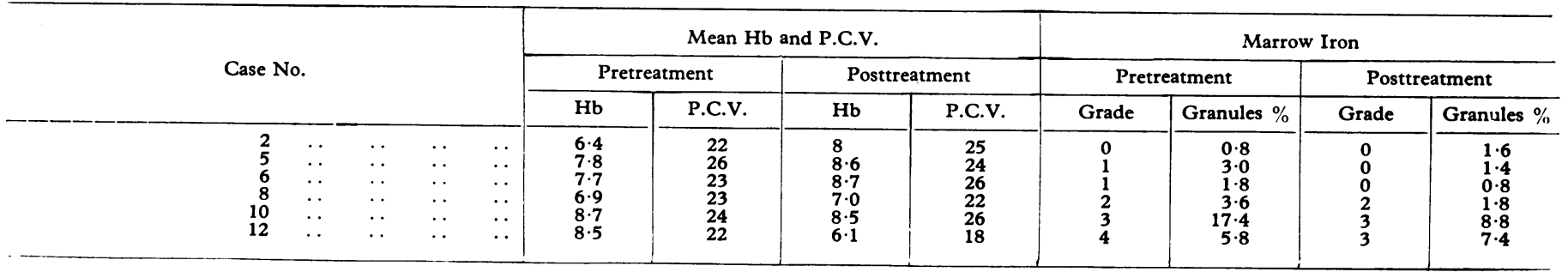


BRITISH MEDICAL JOURNAL

TABLE III-Radioisotope Studies

\begin{tabular}{|c|c|c|c|c|c|}
\hline $\begin{array}{l}\text { Case } \\
\text { No. }\end{array}$ & $\begin{array}{l}\text { Red Cell } \\
\text { Mass (ml) }\end{array}$ & $\underset{\%^{*}}{\stackrel{59}{5 e}}$ & $\begin{array}{c}{ }^{59} \mathrm{Fe} \\
\text { Retention } \\
\% \%^{*}\end{array}$ & $\begin{array}{c}\text { Utilization } \\
\text { of } \\
\text { Oral } \\
\text { Dose } \% \dagger\end{array}$ & $\begin{array}{c}\text { Utilization } \\
\text { of } \\
\text { Intravenous } \\
\text { Dose \% }\end{array}$ \\
\hline $\begin{array}{r}1 \\
2 \\
3 \\
4 \\
5 \\
6 \\
7 \\
8 \\
9 \\
10 \\
11 \\
12 \\
13\end{array}$ & $\begin{array}{r}658 \\
950 \\
1,230 \\
\overline{507} \\
917 \\
880 \\
930 \\
825 \\
1,070 \\
\overline{965} \\
735\end{array}$ & $\begin{array}{r}23 \\
41 \\
48 \\
43 \\
59 \\
4 \\
30 \\
40 \\
13 \\
27 \\
28 \\
16 \\
29\end{array}$ & $\begin{array}{r}28 \\
12 \\
43 \\
40 \\
65 \\
5 \\
26 \\
8 \\
16 \\
10 \\
10 \\
8 \\
8\end{array}$ & $\begin{array}{l}71 \pm 3 \\
78 \pm 7 \\
69 \pm 3 \\
77 \pm 4 \\
66 \pm 2 \\
79 \pm 16 \\
67 \pm 3 \\
63 \pm 9 \\
45 \pm 4 \\
46 \pm 7 \\
64 \pm 13 \\
45 \pm 8 \\
19 \pm 7\end{array}$ & $\begin{array}{l}74 \\
74 \\
75 \\
51 \\
69 \\
73 \\
70 \\
63 \\
84 \\
65 \\
58\end{array}$ \\
\hline
\end{tabular}

Standard deviations due to counting statistics: $* 1 \cdot 0 . ; \dagger$ as indicated

The mean retention of iron in the patients on renal dialysis who were anaemic but not iron deficient was $11.3 \%$. The mean retention of iron in the seven iron-deficient patients was $31.2 \%$, and five out of seven showed levels of retention seen in the iron-deficient control subjects though the values tended to the lower part of the range. Retention of iron diminished as the marrow iron stores increased (Fig. 2).

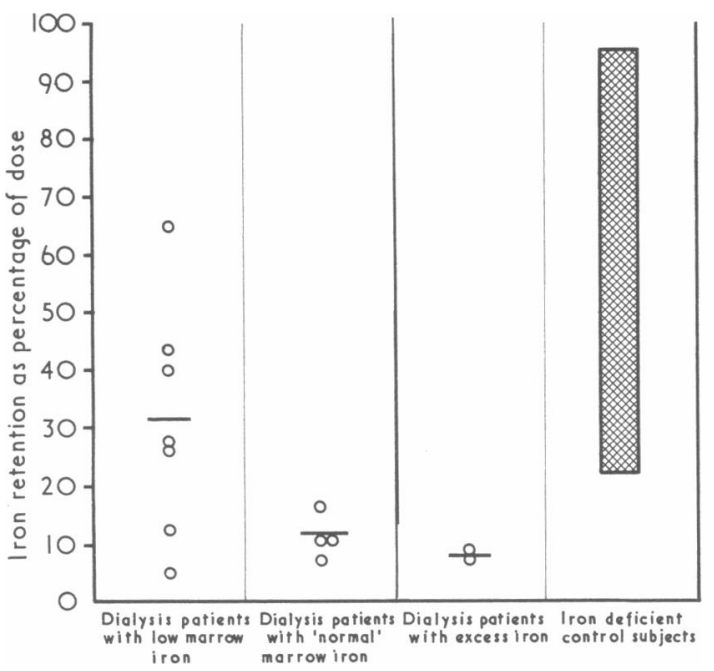

FIG. 2-Retention of ${ }^{59} \mathrm{Fe}$ in iron-deficient control subjects and patients on regular dialysis.

The absorption of iron measured by the chromium chloride marker technique showed poor correlation with the retention values even in the iron-deficient patients where agreement had been good in previously reported studies. Reproducibility of results from successive daily samples was also poor. It is possible that there is poor mixing of the iron and chromium in these patients who take an unusual diet.

The utilization of the orally ingested iron for haemoglobin formation was greater than $45 \%$ in all patients except the iron-laden patient (Case 13). Though the utilization of ${ }^{59} \mathrm{Fe}$ was less than that sometimes seen in iron-deficient nonuraemic subjects, nevertheless 66 to $78 \%$ was available in the iron-deficient group for haemoglobin formation. The discrepancy between the utilization of the oral ${ }^{59} \mathrm{Fe}$ and intravenous ${ }^{59} \mathrm{Fe}$ was notable in Cases 5 and 6 where the latter was less well utilized. In four patients (Cases 9, 10, 12, and 13) the reverse was true. Since these studies were carried out at different times other factors such as menstruation or episodes of infection could have been responsible. In half the patients studied there was equally good utilization of the oral and intravenous iron.
STUDIES ON IRON LOSS

The mean daily loss of iron given as a percentage of the mean total body count was found to be in the range 0.02 to $1.3 \%$ per day, with a standard deviation due to counting statistics usually less than $0.01 \%$ per day. The loss of iron in control subjects using this method is $0.03 \%$ per day (Holt et al., 1967). In 11 patients who completed these studies two (Cases 6 and 10 ) showed normal daily iron loss $(0.02$ to $0.04 \%$ per day), five (Cases $3,7,8,12$, and 13) showed intermediate losses $(0.14$ to $0.25 \%$ per day), and the other four (Cases 1,2 , 5 , and 9) showed heavy iron loss $(0.3$ to $1.3 \%$ per day). This loss was not uniform over the period of the study (Fig. 3).

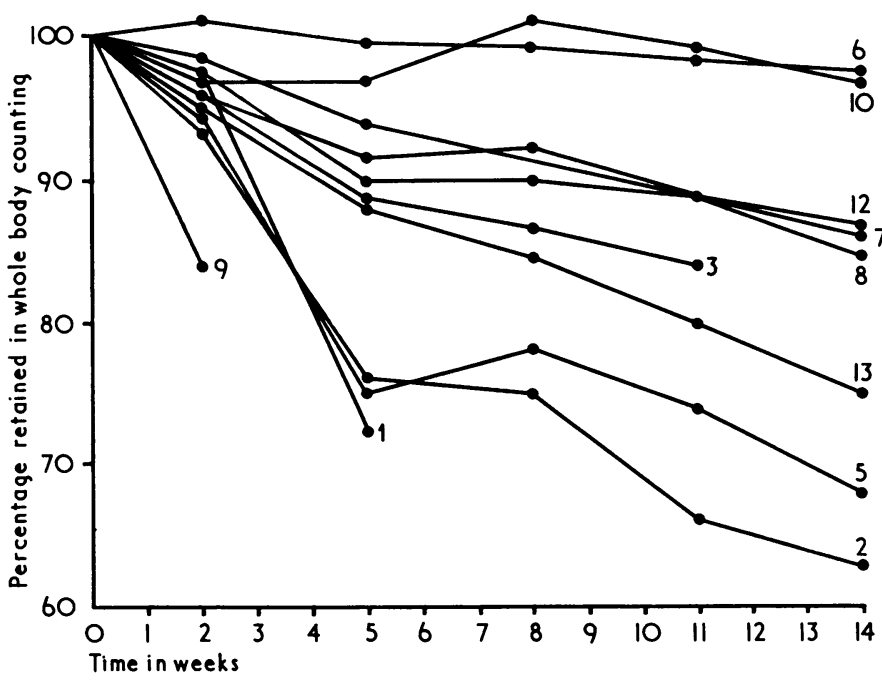

FIG. 3-Loss of iron on serial whole body counting in 11 patients on regular dialysis. Standard deviation due to counting statistics for each point was $<0.5 \%$ of administered dose. For a detailed discussion of the various errors of the measurement see Cottrall et al. (1968).

The steep fall in the activity in Cases 2 and 5 between the second and fifth week was related to clotting of the shunt and menorrhagia in Case 5 and a bleed into the dialyser in Case 2. The variation in the volume of blood lost into the membranes and lines in seven patients is shown in Table IV. The very big losses relate to accidents, but losses of between 5 and $20 \mathrm{ml}$ were common and indicate how easily iron deficiency can develop insidiously in these patients.

TABLE IV-Blood Loss in Dialysis Membranes and Lines

\begin{tabular}{|c|c|c|c|c|c|}
\hline \multirow[t]{2}{*}{ Case No. } & & \multirow{2}{*}{$\begin{array}{l}\text { No. of } \\
\text { Dialyses } \\
\text { in Period }\end{array}$} & \multicolumn{3}{|c|}{$\begin{array}{l}\text { Volume of Blood left in } \\
\text { Membranes and Lines per } \\
\text { Dialysis (ml) }\end{array}$} \\
\hline & & & Min.* & Max. $t$ & Mean \\
\hline $\begin{aligned} 2 & \cdots \\
3 & \cdots \\
5 & \cdots \\
6 & \cdots \\
8 & \cdots \\
10 & \cdots \\
12 & \cdots\end{aligned}$ & $\begin{array}{l}. \\
\because \\
\because \\
\because \\
\cdots \\
.\end{array}$ & $\begin{array}{l}36 \\
18 \\
31 \\
28 \\
24 \\
28 \\
26\end{array}$ & $\begin{array}{l}5.5 \\
0.4 \\
0.7 \\
1.5 \\
3.8 \\
0.6 \\
1.9\end{array}$ & $\begin{array}{r}634 \\
140 \\
299 \\
36 \\
36 \\
35 \\
16\end{array}$ & $\begin{array}{c}68 \\
20 \\
22 \\
7.0 \\
10 \\
5.8 \\
5.8\end{array}$ \\
\hline
\end{tabular}

Standard deviation due to counting statistics: $* 0.2$ to $0.6 ;$ t0.7 to 8.0

The results of the studies on the half-life of iron and chromium are similar to results previously reported. The ${ }^{59} \mathrm{Fe}$ half-life was in the range 39 to 156 minutes and that for ${ }^{51} \mathrm{Cr}$ 15 to 24 days. Shortening of the red cell life is seen in some patients with chronic renal failure and may contribute to the anaemia in this condition. Patients on regular dialysis show this feature. In two patients (Cases 2 and 5) this apparent shortening was also related to the excessive blood loss occurring at the time. 


\section{Discussion}

These studies show that patients on regular dialysis who are iron deficient will respond to oral iron therapy, and also that in these patients the state of the body's iron stores still influences absorption. The marrow iron stores are the most valuable guide to the need for treatment with iron and this confirms the observations of Edwards et al. (1970). The level of absorption in our iron-deficient patients did not approach those reported by Escbach et al. (1970). The two groups of patients may not be comparable, but their finding that iron absorption was entirely compatible with their patients' requirements was not confirmed in this study. The failure of the patients in the present study to replenish their marrow iron stores suggests that prolonged therapy may be required by those on regular renal dialysis.

Utilization of iron for haemoglobin formation occurred at the rate seen in the studies on intravenous iron by Carter $e t$ al. (1969), but there is no evidence that parenteral iron only was capable of being utilized. Parenteral iron is not more effective, and unless the requirement is carefully calculated and the result of treatment assessed from the marrow iron serious overload may develop

The rate of blood loss varied considerably in these patients, and individuals could show pronounced variation in mean loss at dialysis in successive periods. The patient with the insidious loss of from 5 to $30 \mathrm{ml}$ of blood per dialysis is most at risk as this may not be appreciated. It is in this group that prolonged oral iron therapy would be beneficial.

We would like to acknowledge the help of Sister A. Dobson and Sister H. de L. Nichols at the Renal Dialysis Centre; Mr. L. Millbank, of the department of haematology, St. Bartholomew's Hospital, for his help with the folate estimations; and Mr. N. K.
Gupta and Mrs. A. Stringer, of the physics department and radiotherapy department respectively at the Royal Marsden Hospital, Sutton. We would also like to thank Mr. P. J. Cull and Mr. W. D. Tredinnick, of the department of medical illustration, St. Bartholomew's Hospital.

Requests for reprints should be sent to Dr. J. S. Malpas.

\section{References}

Boender, C. A., and Verloop, M. C. (1969). British fournal of Haematology, 17,45

Brozovich, B. (1971). In press.

Brozovich, B., and Copestake, J. (1969). Fournal of Clinical Pathology, 22 605.

Carter, R. A., Hawkins, J. B., and Robinson, B. H. B. (1969). British Medical fournal, 3, 206.

Cottrall, M. F., Stringer, A. M., and Trott, N. G. (1968). Radioaktive Isotope in Klinik und Forschung, 8, 122. (Urban and Schwarzenberg, Munich)

Cottrall, M. F., and Trott, N. G. (1971). Radioaktive Isotope in Klinik und Forschung, 9, 161. (Urban and Schwarzenberg, Munich)

Crockett, R. E., et al. (1967). Proceedings of the European Dialysis and Transplant Association, 4, 17.

Curtis, J. R., et al. (1969). Quarterly fournal of Medicine, 38, 49.

Dacie, J. V., and Lewis, S. M. (1968). Practical Haematology, 4th edn. London, Churchill.

Edwards, M., Pegrum, C. D., and Curtis, J. R. (1970). Lancet, 2, 491.

Escbach, J. W., Cook, J. D., and Finch, C. A. (1970). Clinical Science, 38,

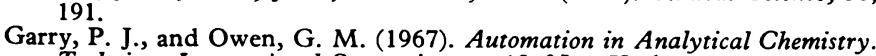
Technicon International Symposium, p. 18. New York.

Holt, J. M., Mayet, F. G. H., Warner, G. T., and Callender, S. T. (1967) British Medical Fournal, 4, 86.

Holt, J. M., Mayet, F. G. H., Warner, G. T., Callender, S. T., and Gunning, A. J. (1968). British Medical Fournal, 3, 22.

Millbank, L., Davis, R. E., Rawlings, M., and Waters, A. H. (1970). fournal of Clinical Pathology, 23, 54 .

Najean, Y., and Ardaillou, N. (1963). Nouvelle Revue française d'Hématologie, 3, 82.

Rath, C. E., and Finch, C. A. (1948). Journal of Laboratory and Clinical Medicine, 33, 81.

\title{
Effect of Measles Vaccination on Incidence of Measles in the Community
}

\author{
IAN SUTHERLAND, P. M. FAYERS
}

British Medical fournal, 1971, 1, 698-702

\section{Summary}

A study of the effect of measles vaccination on the incidence of the disease in eight separate areas of England and Wales was begun in 1966. It showed an inverse association between the proportion of children vacsinated and the incidence of measles in the area in the following year, but measles epidemics occurred in several of the areas in subsequent years, despite continuing vaccinations.

Measles vaccination was introduced on a large scale in Britain in 1968. Analysis of the notification and vaccination statistics shows that the vaccination of about $10 \%$ of the child population (under 15 years) in 1968 sufficed to "replace" the measles epidemic which had bcen expected in the period October 1968 to Sepiember 1959 by a low incidence of the disease, typical of that in previous "interepidemic" years. Further, the effect of the vaccinations was to prevent the develop-

M.R.C. Statistical Research and Services Unit, London WC1E 6AS

IAN SUTHERLAND, M.A., D.PHIL., Director

P. M. FAYERS, B.SC., Scientific Staff Member ment of natural measles in susceptible unvaccinated children as well as in the vaccinated subjects. Thus the number of immune subjects in the community was increased by the vaccinations, but as a result there was a reduction in the number of subjects who acquired immunity from natural measles. These opposed results can therefore explain why vaccination may be effective in the community for only a year or two, though vaccination protects the individual for much longer.

It is estimated that a continuing vaccination rate of $\mathbf{4 0}$ to $50 \%$ of the children born each year would be necessary to replace the regular biennial measles epidemics in Britain by a continuous endemic incidence, and might perhaps lead to the disappearance of the disease without a further major epidemic, but that a continuing vaccination rate of 80 to $90 \%$ of children born each year would then be necessary to prevent its reintroduction. The long-term control of measles by vaccination will thus probably prove more difficult than for any other infectious disease.

\section{Introduction}

At the instigation of the M.R.C. Measles Vaccines Committee a study was begun in 1966 of the effect of measles vaccina- 